\title{
SISTEM KENDALI OTOMATIS PADA PEMERAH SUSU SAPI DENGAN MENGGUNAKAN SENSOR LIGHT DEPENDENT RESISTOR (LDR)
}

\author{
Mochamad Choifin ${ }^{1}$, Wiji Lestariningsih ${ }^{2}$ \\ Teknik Mesin, Fakultas Teknik \\ Universitas Maarif Hasyim Latif, Sidoarjo, Indonesia \\ e-mail : ${ }^{1}$ mochamad_choifin@dosen.umaha.ac.id, ${ }^{2}$ wiji_lestariningsih@dosen.umaha.ac.id \\ Diterima: 3 Maret 2019. Disetujui : 15 Juni 2019. Dipublikasikan : 30 Juni 2019

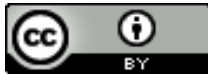 \\ (C)2019 -TESJ Fakultas Teknik Universitas Maarif Hasyim Latif. Ini adalah artikel dengan \\ akses terbuka di bawah lisensi CC BY 4.0 (https://creativecommons.org/licenses/by/4.0/)
}

\section{ABSTRAK}

\begin{abstract}
Mesin pemerah Susu Sapi merupakan salah satu cara untuk meningkatkan produktifitas pemerahaan yang pada saat ini. Sistem pemerahan susu yang telah ada bekerja secara mekanis dan tidak bisa mendeteksi volume susu yang ada pada kantung sapi, sehingga banyak peternak yang tidak bisa memaksimalkan volume susu sapi yang tersisa saat pemerahan. Adapun cara memaksimalkan produksi susu sapi peternak menunggu masa pulsasi selesai, hal ini juga akan membuat sapi merasa trauma. Dalam penelitian ini akan dilakukan Perancangan sistem pemerah secara otomatis menggunakan sensor aliran dengan mikrokontroller ATMEGA 8, sehingga dapat mengendalikan proses pemerahan serta dapat memaksimalkan volume susu yang dihasilkan saat proses pemerahan. Metode otomatis yang digunakan pada alat ini menggunakan sensor aliran berupa dengan sensor LDR Light Dependent Resistor yang berupa rangkaian guna mendeteksi aliran susu sapi tersebut guna mengetahui besar aliran susu. Sementara hasil pengukuran data pengujian pada kondisi maksimum ketika sensor LDR terang 1 unit didapatkan kapasitas susu sapi sebesar 7,871 ml/detik. Semakin bertambahnya sensor LDR yang terang akan mengalami penurunan kapasitas pula. Ketika kondisi susu sapi kritis atau minimum kapasitas yang dihasilkan sebesar 0,461 ml/detik pada saat sensor LDR terang 6 unit.
\end{abstract}

Kata kunci : mikrokontroller, ATMEGA 8, sensor LDR

\section{PENDAHULUAN}

Untuk memaksimalkan produksi susu sapi perlu dikembangkannya sistem pemerah susu serta teknik pengambilan susu sapi dengan tepat. Pada tahun 1820 pertama kali ditemukan peralatan yang sangat sederhana untuk mengeluarkan susu dari sapi. Pada mesin ini dirasa sangat tidak efektif karena peralatan masih sangat sederhana sehingga pemerahan kurang maksiamal, Selanjutnya mesin perah yang pertama diciptakan dan dikeluarkan pada tahun 1850 oleh seorang petani dari Amerika yang bemama Anna Baldwin. Alat tersebut berbentuk sebuah pompa yang dihubungkan dengan pipa yang berujung pada sebuah mangkok yang berlubang empat untuk menyedot susu dari keempat puting.

Di ujung lain digantungkan sebuah ember guna menampung susu hasil pemerahan. Pada mesin ini pemerahan susu masih menggunakan pompa dragon sehingga masih menggunakan tenaga manusia untuk menggerakkan pompa. Selain itu hasil susu masih kurang hiegenis karena sistem melalui pompa yang tidak steril.

Pada periode waktu sebelumnya, para peternak menggunakan metode manual dalam proses pemerahan susu sapi yaitu dengan cara peternak memerah susu dengan menggunakan tangan untuk memijat kantung susu guna mendapatkan susu dan susu ditampung dalam bak penampung.

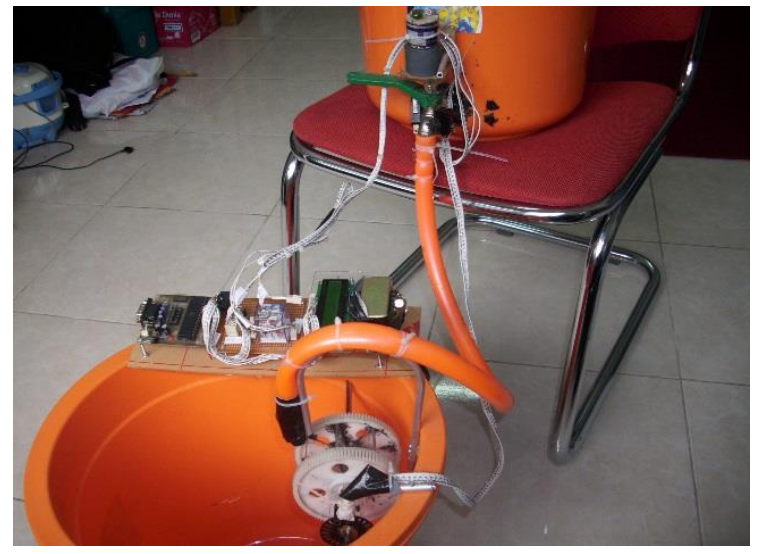

Gambar 1. Simulator pemerah susu otomatis yang dirancang Tito Pradana Putra (Putra, 2008)

Sementara itu, Tito Pradana Putra (Putra, 2008) melalui tugas akhir nya telah merancang simulator pemerah susu otomatis menggunakan sensor aliran seperti terlihat pada Gambar 1. Pada rangkaian simulator ini digunakan sensor aliran (flow sensor) untuk mendeteksi jumlah aliran, 
sedangkan pompa vacum diilustrasikan sebagai pompa air yang dikendalikan oleh mikrokontroler. Hasil simulator menunjukkan performa sistem pemerah sebenarnya, dimana pada saat aliran mulai berkurang maka akan menghentikan pompa.

\section{METODE PENELITIAN}

Dalam penelitian ini akan dihasilkan alat pemerah susu otomatis guna meningkatkan produktivitas susu perahan. Untuk dapat mencapai hasil tersebut maka langkah-langkah utama pada program ini yang akan dilakukan adalah: kajian literatur, observasi, perencanaan implementasi alat pemerah susu sapi otomatis, pemilihan komponen, assembly alat pemerah susu sapi, pengujian prototipe dan pembuatan laporan.

\section{Kaji literatur}

Langkah awal dari program ini adalah kajian literatur yang berkaitan dengan sistem pemerah susu tradisional, sistem pemerah susu mekanik dan sistem kendali otomatis. Pada langkah ini juga dilakukan kaji desain kendali otomatik pada simulator pemerah susu otomatik yang telah dirancang oleh Tito Pradana Putra (Putra, 2008) sebagai pembanding sekaligus sebagai acuan dalam implementasi dalam pembuatan alat pemerah susu otomatik.

\section{Observasi}

Tahap ini dilakukan pengamatan secara langsung terhadap karakteristik, desain dari alat pemerah susu sapi mekanis. Observasi ini dilakukan di peternak susu sapi yang berada di kelompok ternak sapi unggulan kabupaten Pasuruan Jawa Timur.

\section{Perencanaan implementasi alat pemerah susu sapi otomatis}

Pada langkah ini dilakukan perencanaan implementasi dari sistem pemerah susu sapi dangan didasari pada hasil kaji literatur, kaji karakteristik, desain, dan dimensi dari produk yang sudah ada. Adapun rancangan konsep kendali otomatis pada sistem pemerah susu otomatis terlihat pada Gambar 2.

\section{Pemilihan komponen}

Setelah dibuat perencanaan implementasi alat pemerah susu sapi, kemudian dilakukan pemilihan komponen-komponen yang nantinya akan dipakai dalam membuat prototipe alat pemerah susu otomatik. Pemilihan komponen diutamakan pada komponen yang sudah ada di pasaran baik jenis maupun spesifikasinya.

\section{Assembly alat pemerah susu sapi}

Tahap assembly prototipe ini didasarkan pada jenis komponen yang telah dipilih dan kebutuhan sistem yang diperlukan. Kemudian dibuat prototipe atau produk yang siap untuk diuji di lapangan.

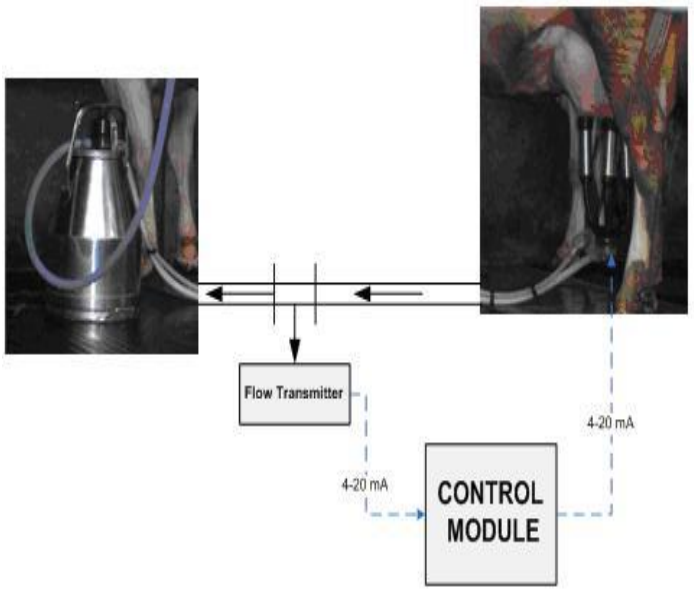

Gambar 2. Konsep kendali otomatis pada alat pemerah susu otomatis

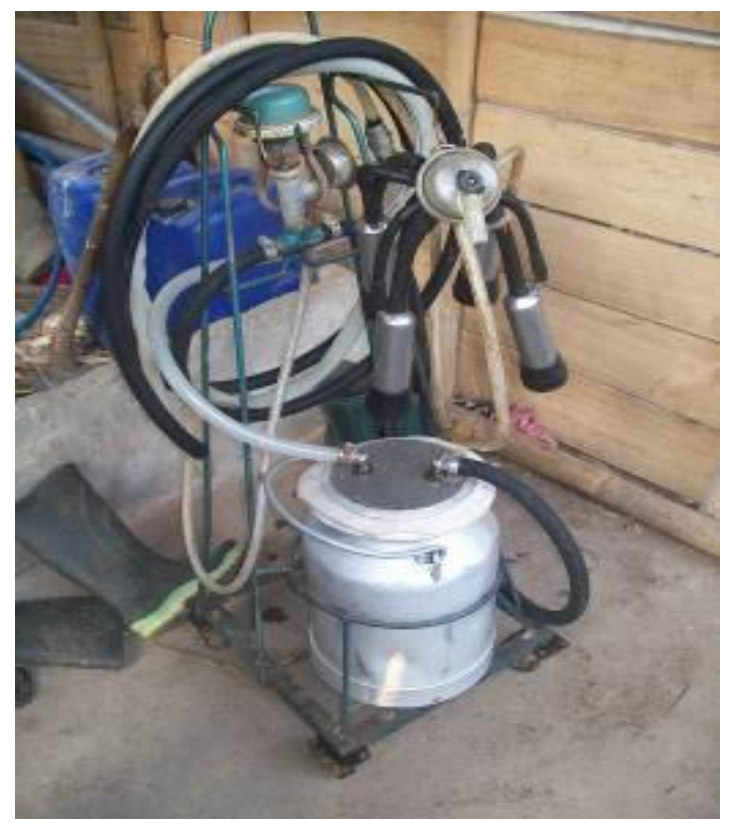

Gambar 3. Alat pemerah susu mekanis

\section{Pengujian prototipe}

Setelah prototipe disempurnakan sesuai dengan kondisi dan kebutuhan dalam proses pemerahan susu sapi, maka dilakukan pengujian alat. Pengujian dilakukan untuk mendapatkan hasil pemerahan susu dan membandingkan dengan hasil pemerahan yang dilakukan secara tradisional ataupun dengan alat pemerah susu mekanis. Dan juga diadakan analisa terhadap trauma pada sapi sewaktu proses pemerahan susu. Jika hasil pengujian sesuai dengan perencanaan yang telah dilakukan maka akan diteruskan pada tahap selanjutnya, jika tidak maka akan diadakan perencanaan kembali. 


\section{Pembuatan laporan}

Langkah terakhir dari kegiatan ini yaitu penyusunan laporan yang bertujuan agar terdapat bukti otentik yang menunjukan bahwa pernah dilakukan pengujian.

\section{HASIL DAN PEMBAHASAN}

\section{Perencanaan dan Perancangan Sistem}

Hasil rancangan komputer berupa rangkaian elektronika sistem kendali pemerah susu sapi otomatis dengan menggunakan mikrokontroller ATMEGA8 dengan menggunakan soft ware Proteus 7.4 Sp3. Sedangkan hasil perancangan prototipe sistem kendali pemerah susu sapi otomatis beradasarkan pada konsep awal diaplikasikan pada pemerahan secara riil yang ada di lapangan nantinya akan dikomparasikan antara data acuan dan data hasil pengujian. Dimana data acuan direncanakan yang nantinya sebagai input untuk membuka dan menutup katup claw yang digerakkan oleh solenoid valve.

\section{Rancang Bangun Prototipe Sistem Kendali Pemerah Susu Sapi Otomatis}

Hasil prototipe sistem Kendali Pemerah Susu Sapi otomatis, seperti terlihat pada Gambar 4 .

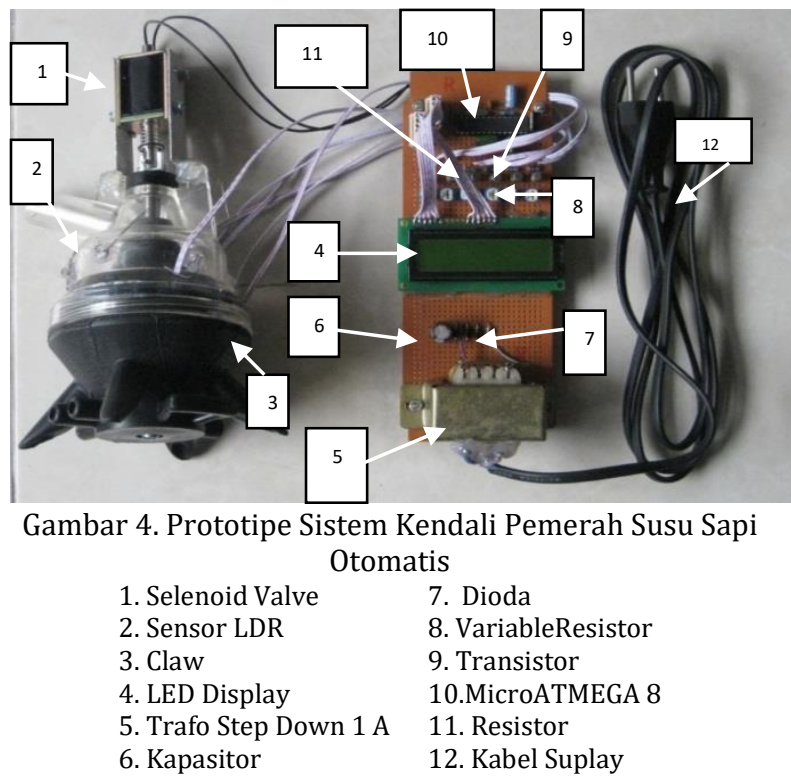

\section{Sistem Kendali Pemerah Susu Sapi otomatis}

Hasil rancangan sistem Kendali Pemerah Susu Sapi otomatis, seperti terlihat pada Gambar 6 . Kerja dari sistem kendali pemerah susu otomatis ini adalah saat susu yang ada pada ambing sapi akan habis dapat diketahui dengan adanya berkurangnya aliran yang mengalir pada claw. Sehingga sensor LDR yang dipasang pada bagian Luar claw akan mendeteksi tingkat intensitas cahaya yang ada. Dimana sifat dari tahanan LDR ini adalah nilai tahanannya akan berubah apabila terkena sinar atau cahaya. Apabila tidak terkena cahaya nilai tahanannya akan besar dan sebaliknya apabila terkena cahaya nilai tahanannya akan menjadi kecil. Semakin sedikit aliran susu sapi pada claw artinya tahanannya akan kecil yang nantinya sebagai input pulsa yang masuk pada mikroprosesor, tepatnya masing-masing pulsa masuk melalui port $B$ yang kemudian di dalam mikroprosesor ini memproses dan mengolah pulsa menjadi tegangan yang nantinya digunakan sebagai driver relai untuk menggerakkan actuator yang berupa selenoid valve yang mengendalikan katup buka-tutup untuk mengakhiri proses pemerahan susu sapi. Jadi ketika aliran susu sapi yang diperah mulai habis Sensor LDR yang digunakan untuk membaca pulsa memberikan perintah untuk mengakhiri proses pemerahan.

\section{Hasil Perancangan dengan Software Proteus 7.4 sp3}

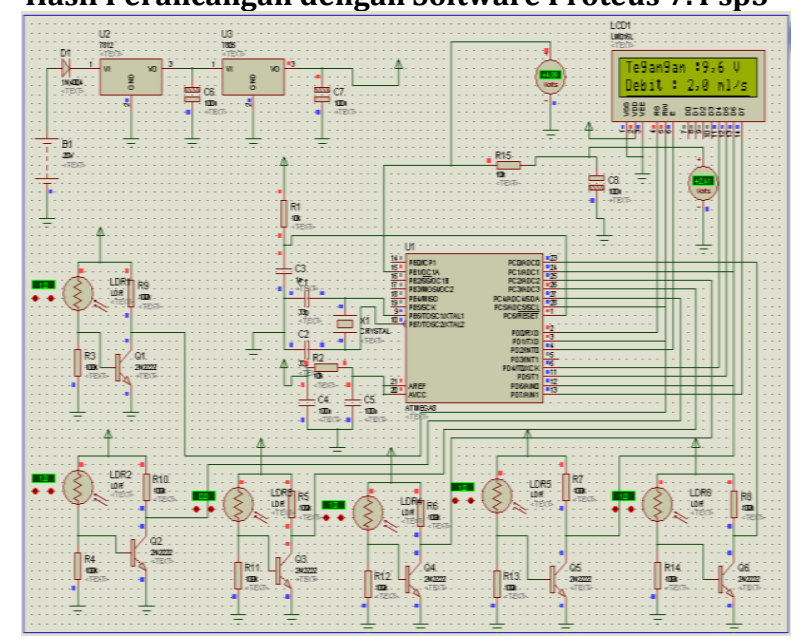

Gambar 5. Rangkaian Elektronika Sistem kendali pemerah susu sapi otomatis

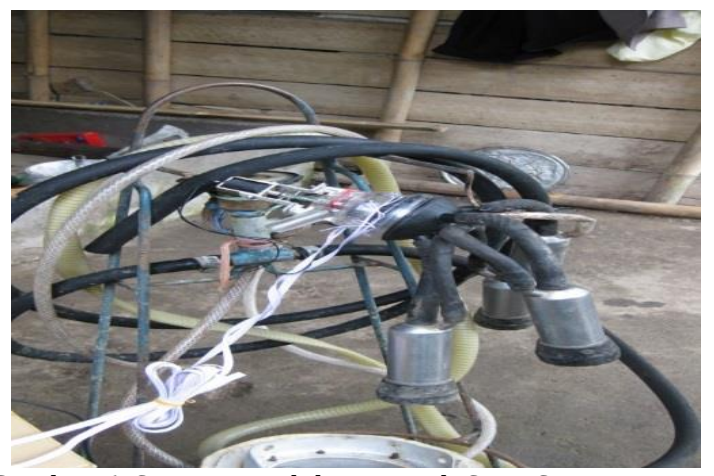

Gambar 6. Sistem Kendali Pemerah Susu Sapi otomatis

\section{Data Acuan dan Grafik Data Acuan Data Acuan}

Data ini sebagai acuan atau inputan pada mikrokontroller ATMEGA8 yang mana nantinya berfungsi sebagai komparasi data riil yang ada di lapangan. Data acuan ini diambil berdasarkan observasi di peternak susu sapi yang berada di 
kelompok ternak sapi unggulan kabupaten Pasuruan Jawa Timur. Bahwa kapasitas pemerahan susu sapi pada umumnya sekitar 4 liter per 10 menit yang setara dengan $6,6 \mathrm{ml} /$ detik.

Bahwa pada data acuan ini yang mana Sensor LDR yang dipasang berjumlah 6 unit berfungsi sebagai sensor untuk mendeteksi jumlah kapasitas susu sapi berdasarkan jumlah sensor LDR yang menyala pada saat proses pemerahan. Dimisalkan apabila sensor LDR terang 1 dan mati 5 kapasitas yang dihasilkan sebesar 7,917 ml/ detik dan seterusnya. karena pada posisi sensor LDR terang 6 dengan kapasitas susu sapi sebesar 0,242 $\mathrm{ml} /$ detik terlalu sedikit kapasitas yang dihasilkan, maka dari mikrokontroller kita program proses pemerahan kita hentikan pada sensor LDR terang 5 unit dengan kapasitas susu sapi yang dihasilkan sebesar 2,203ml/detik.

Tabel 1. Data Acuan

\begin{tabular}{c|c|c|c|c|c|c}
\hline No & $\begin{array}{c}\text { LDR } \\
\text { terang } \\
\mathbf{1}\end{array}$ & $\begin{array}{c}\text { LDR } \\
\text { terang } \\
\mathbf{2}\end{array}$ & $\begin{array}{c}\text { LDR } \\
\text { terang } \\
\mathbf{3}\end{array}$ & $\begin{array}{c}\text { LDR } \\
\text { terang } \\
\mathbf{4}\end{array}$ & $\begin{array}{c}\text { LDR } \\
\text { terang } \\
\mathbf{5}\end{array}$ & $\begin{array}{c}\text { LDR } \\
\text { terang } \\
\mathbf{6}\end{array}$ \\
\hline 1 & 7,967 & 4,635 & 4,086 & $\mathbf{2 , 5 6 5}$ & 2,238 & 0,354 \\
\hline 2 & 7,939 & 4,498 & 3,965 & 2,838 & 2,187 & 0,331 \\
\hline 3 & 7,847 & 5,928 & 3,829 & 2,947 & 2,185 & 0,043 \\
\hline $\begin{array}{c}\text { Rata-rata } \\
\text { (ml/detik) }\end{array}$ & $\mathbf{7 , 9 1 7}$ & $\mathbf{5 , 0 2 0}$ & $\mathbf{3 , 9 6 0}$ & $\mathbf{2 , 7 8 3}$ & $\mathbf{2 , 2 0 3}$ & $\mathbf{0 , 2 4 2}$ \\
\hline
\end{tabular}

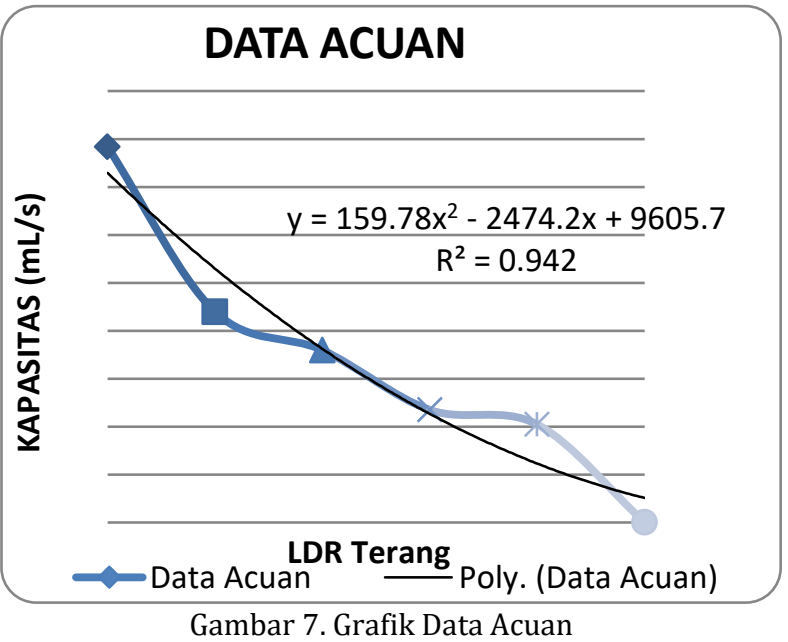

Dari Gambar 7 terlihat bahwa pada data acuan yang dilakukan melalui studi observasi menunjukkan tren penurunan di setiap bertambahnya jumlah sensor LDR yang terang. Artinya semakin banyak Sensor LDR yang terang semakin sedikit pula kapasitas aliran susu sapi.

Pada sensor LDR terang 1 unit dan mati (gelap) 5 unit kapasitas susu sapi yang dihasilkan sebesar 7,917 $\mathrm{ml} /$ detik dan penurunan tren terus terjadi dengan bertambahnya jumlah sensor LDR yang terang diikuti dengan semakin sedikitnya kapasitas susu sapi yang dihasilkan dalam $\mathrm{ml} /$ detik.

Pada sensor LDR terang 6 unit artinya sensor terang semua tidak ada yang gelap kapasitas susu sapi yang dihasilkan sebesar 0,242 ml/detik. Kondisi ini mengindikasikan bahwa susu sapi yang diperah akan habis.

\section{Data Hasil Pengujian dan Analisa Grafik Hasil Pengujian \\ Data Hasil Pengujian}

Data ini diambil berdasarkan pengujian di peternakan susu sapi di kelompok ternak sapi unggulan kabupaten Pasuruan Jawa Timur.

Tabel 2. Data Hasil Pengujian

\begin{tabular}{c|c|c|c|c|c|c}
\hline No & $\begin{array}{c}\text { LDR } \\
\text { terang } \\
\mathbf{1}\end{array}$ & $\begin{array}{c}\text { LDR } \\
\text { terang } \\
\mathbf{2}\end{array}$ & $\begin{array}{c}\text { LDR } \\
\text { terang } \\
\mathbf{3}\end{array}$ & $\begin{array}{c}\text { LDR } \\
\text { terang } \\
\mathbf{4}\end{array}$ & $\begin{array}{c}\text { LDR } \\
\text { terang } \\
\mathbf{5}\end{array}$ & $\begin{array}{c}\text { LDR } \\
\text { terang } \\
\mathbf{6}\end{array}$ \\
\hline 1 & 8,333 & 4,677 & 3,826 & 2,623 & 2,312 & 0,434 \\
\hline 2 & 7,482 & 4,645 & 3,882 & 2,576 & 2,224 & 0,334 \\
\hline 3 & 7,783 & 4,486 & 3,773 & 2,523 & 2,118 & 0,356 \\
\hline 4 & 8,314 & 4,356 & 3,698 & 2,803 & 2,151 & 0,757 \\
\hline 5 & 7,445 & 4,222 & 2,798 & 2,312 & 2,321 & 0,442 \\
\hline $\begin{array}{c}\text { Rata-rata } \\
\text { (ml/detik) }\end{array}$ & $\mathbf{7 , 8 7 1}$ & $\mathbf{4 , 4 7 7}$ & $\mathbf{3 , 5 9 5}$ & $\mathbf{2 , 5 6 7}$ & $\mathbf{2 , 2 2 5}$ & $\mathbf{0 , 4 6 1}$ \\
\hline
\end{tabular}

\section{Analisa Grafik Hubungan Acuan terhadap Pengujian}

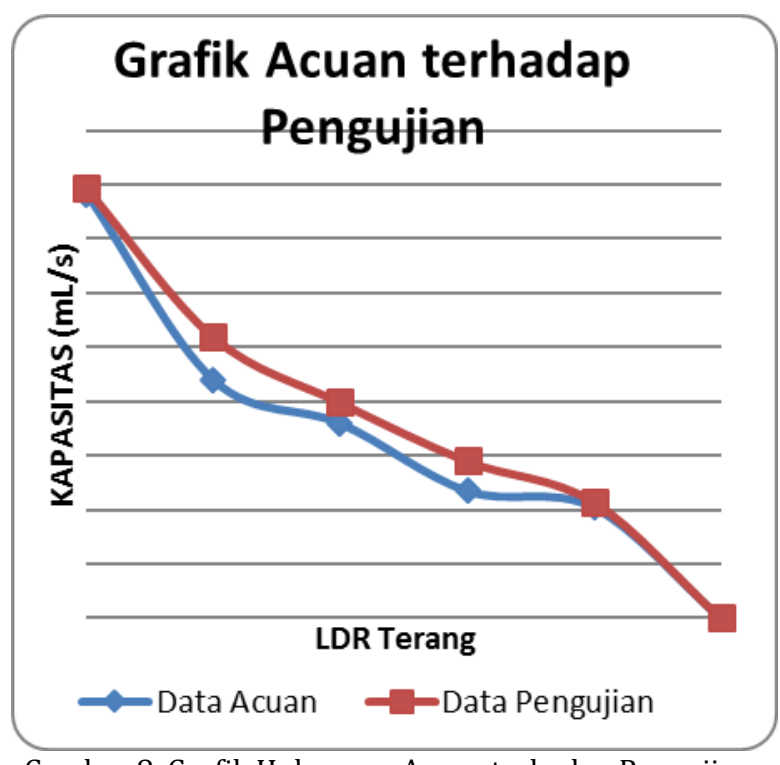

Gambar 8. Grafik Hubungan Acuan terhadap Pengujian

Dari Gambar 8 terlihat bahwa karakteristik trennya sama baik komparasi antara data acuan dan hasil pengujian. Yaitu menunjukkan tren penurunan bersamaan dengan adanya jumlah sensor LDR yang terang terhadap kapasitas susu sapi yang dihasilkan dalam ml/detik. Terlihat hasil pengukuran data acuan pada kondisi maksimum ketika sensor LDR terang 1 unit didapatkan kapasitas susu sapi sebesar 7,917 ml/detik. Dan semakin bertambahnya sensor LDR yang terang pada data acuan terus mengalami penurunan kapasitas. Sampailah di titik minimum atau kritis saat sensor LDR terang 6 unit dengan susu sapi yang di hasilkan sebesar 0,242 ml/detik.

Sementara hasil pengukuran data pengujian pada kondisi maksimum ketika sensor LDR terang 1 unit didapatkan kapasitas susu sapi sebesar 
7,871 ml/detik. Semakin bertambahnya sensor LDR yang terang akan mengalami penurunan kapasitas pula. Ketika kondisi susu sapi kritis atau minimum kapasitas yang dihasilkan sebesar 0,461 $\mathrm{ml} /$ detik pada saat sensor LDR terang 6 unit.

\section{PENUTUP}

Dari hasil rancangan prototipe sistem kendali pemerah susu sapi otomatis, Penelitian yang menghasilkan alat pemerah susu sapi otomatis dapat disimpulkan bahwa:

1. Sensor cahaya (LDR) yang terpasang pada alat pemerah Susu sapi berjumlah 6 Unit

2. Sensor cahaya (LDR) yang terpasang pada claw mampu mendeteksi aliran paling sedikit dengan kapasitas 0,461 ml/detik.

3. Penggunaan sensor LDR dalam sistem kendali ini mampu mengendalikan katup solenoid dari sistem pemerahan sehingga saat susu mulai habis proses pemerahan akan berhenti.

\section{DAFTAR PUSTAKA}

Budi, U., \& dkk. (2006). Dasar Ternak Perah. In Buku Ajar. Medan: Departemen Peternakan FP USU.
Curtis, J. D. (2003). Process Control Instrumentation Technology (3rd ed.). London UK: Prentice Hall International.

Deutschman, A. D., Michels, W. J., \& Wilson, C. E. (1975). Machine design; theory and practice. Prentice Hall.

Dinas Peternakan Provinsi Jawa Barat. (2004). Kajian Pengembangan Model Unit Pelayanan Jasa Alat dan Mesin Peternakan. Bandung.

LAMEL - BLPT Surabaya. (2007). Pemrograman Mikrokontroller AT89S51 Dengan $\mathrm{C} / \mathrm{C}++$ dan Assembler. Yogyakarta: Penerbit Andi.

Putra, T. P. (2008). Simulator Sistem Kendali Pemerah Susu dengan Menggunakan Sensor Kecepatan Aliran. Institut Teknologi Sepuluh Nopember, Surabaya.

Raven, F. H. (1995). Automatic control engineering. McGraw-Hill, Inc.

Roger, L. T. (1995). Elektronika Digital. Erlangga, Edisi II.

U.S. Department of Technology. (1992). Fundamental Handbook of Instrumentation \& Control. Washington D.C.

Willa, L. (2007). Teknik Digital, Mikroprosesor, dan Mikrokomputer. Bandung: Informatika.

Winoto, A. (2008). Mikrokontroler AVR ATmega8. 
M Choifin, dkk / Teknika : Engineering and Sains Journal, Vol. 3, No.1, Juni 2019, 45-50

Halaman ini sengaja dikosongkan 